\title{
Opening and evolution of the South China Sea constrained by studies on volcanic rocks: Preliminary results and a research design
}

\author{
XU YiGang ${ }^{1 *}$, WEI JingXian ${ }^{1,2}$, QIU HuaNing ${ }^{1}$, ZHANG HuiHuang ${ }^{1} \&$ HUANG XiaoLong ${ }^{1}$ \\ ${ }^{1}$ State Key Laboratory of Isotope Geochemistry, Guangzhou Institute of Geochemistry, Chinese Academy of Sciences, Guangzhou 510640, China; \\ ${ }^{2}$ Graduate University of Chinese Academy of Sciences, Beijing 100049, China
}

Received July 27, 2011; accepted November 15, 2011; published online December 30, 2011

\begin{abstract}
The South China Sea (SCS) is characterized by abundant seamounts, which provide important information about the evolution of the SCS and related deep processes. Cenozoic volcanism in the SCS and its surroundings comprises three stages relative to the spreading of the SCS: pre-spreading ( $>32 \mathrm{Ma}$ ), syn-spreading (32-16 Ma), and post-spreading $(<16 \mathrm{Ma})$. The pre-spreading magmatism predominantly occurs on the northern margin of the SCS and in South China coastal areas and shows a bi-modal affinity. The syn-spreading magmatic activity was very limited on the periphery of the SCS, but may be concentrated in the SCS. However, seafloor samples of this stage are not available yet because of overlying thick sedimentary deposits. Post-spreading magmatism is widespread in the central and southwest sub-basins of the SCS, Hainan Island, Leizhou Peninsula, Thailand, and Vietnam. These are mainly alkali basalts with subordinate tholeiites, and display OIB-type geochemical characteristics. The Dupal isotope anomaly and presence of high-magnesian olivine phenocrysts suggests their possible derivation from the Hainan mantle plume. The temporal and spatial distribution of Cenozoic volcanism in the SCS and its surroundings may be accounted for either by plate stress re-organization before and after SCS spreading, or by ridge suction of plume flow during opening of the SCS. If the latter is the case, the volcanic rocks within the SCS basin may not be typical mid-ocean ridge basalts (MORB). It remains puzzling, however, that the transition between the South China continental margin and the SCS basin does not have features typical of a volcanic rifted margin. Clearly, the relationship between mantle plume and SCS opening needs further evaluation. A better understanding of the link between deep processes and opening of the SCS not only requires enhanced studies on igneous petrogenesis, but also is heavily dependent on systematic sampling of seafloor rocks.
\end{abstract}

volcanism, mantle melting, rifting continental margin, opening of the South China Sea, Hainan mantle plume

Citation: $\quad \mathrm{Xu} \mathrm{Y} \mathrm{G,} \mathrm{Wei} \mathrm{J} \mathrm{X,} \mathrm{Qiu} \mathrm{H} \mathrm{N,} \mathrm{et} \mathrm{al.} \mathrm{Opening} \mathrm{and} \mathrm{evolution} \mathrm{of} \mathrm{the} \mathrm{South} \mathrm{China} \mathrm{Sea} \mathrm{constrained} \mathrm{by} \mathrm{studies} \mathrm{on} \mathrm{volcanic} \mathrm{rocks:} \mathrm{Preliminary} \mathrm{results} \mathrm{and} \mathrm{a}$ research design. Chin Sci Bull, 2012, 57: 3150-3164, doi: 10.1007/s11434-011-4921-1

One of the main tasks of the National Natural Science Foundation of China (NSFC) program on "The South China Sea Deep" is to understand the formation and evolution of the South China Sea (SCS). Debates persist about the timing of the SCS spreading and relevant geodynamic processes. The current popular view, which is largely built on seafloor magnetic anomalies, is that the opening of the SCS started at $32 \mathrm{Ma}$ and ended at 15.5 Ma[1-3]. However, Hsu et al. [4] argued for an earlier opening at $37 \mathrm{Ma}$, based on newly acquired bathymetry and magnetic data. The SCS basin

*Corresponding author (email: yigangxu@gig.ac.cn) comprises the south-west sub-basin, central sub-basin, and east sub-basin. Did these basins form in a homogenous way in time and space? Did the oceanic crust form during SCS spreading? In addition, recent seismic studies revealed a low-velocity structure in the mantle beneath Hainan Island, which appears to rise from a depth of at least $1900 \mathrm{~km}$ [5-7]. Named the Hainan mantle plume, it may be responsible for the wide-spread Cenozoic alkali basalts in the Leizhou Peninsula, Hainan Island, SCS, and Indochina, affecting an area of over $4 \times 10^{6} \mathrm{~km}^{2}$ (Figure 1) [8]. If the Hainan mantle plume does exist, the relevant questions include the following: Was the plume activity responsible for the opening of 


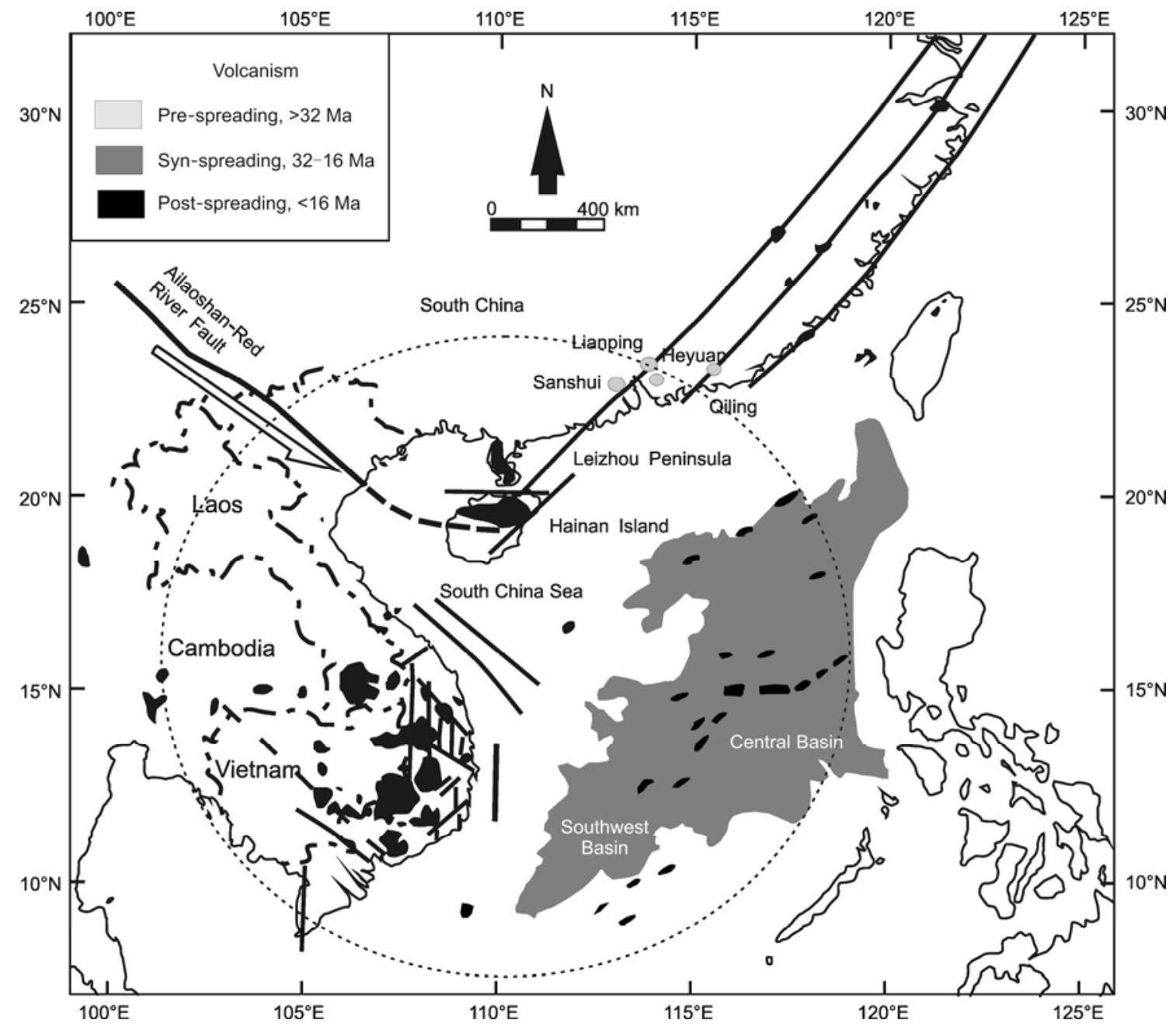

Figure 1 Simplified map showing the distribution of Cenozoic volcanic rocks in the South China Sea and its surroundings (modified after [9-12]). The distribution of syn-spreading magmas is inferred from seafloor magnetic anomalies [1,11]. The dashed circle outlines the area affected by the Hainan plume [8].

the SCS? Did the linear distribution of seamounts in the SCS result from the Hainan mantle plume?

Age determination and compositional analyses of samples from the oceanic crust and seamount chains enable us to constrain the formation age of the SCS basin and related deep processes. Two types of oceanic basalts may be present in the SCS basin, i.e. mid-ocean ridge basalts (MORB) and oceanic island basalts (OIB). Of course, in the circumstance of ridge-plume interaction, magmas produced may have compositions intermediate between MORB and OIB [13]. MORB represents the samples of oceanic crust. If its temporal and spatial distribution can be defined, one can directly constrain the formation of the oceanic basin, and the style and rate of sea spreading. OIB results from partial melting of the convective mantle, and its composition is dependent upon a number of parameters, such as source characteristics, melting degree, mantle potential temperature, and lithospheric thickness. If the relative contribution of these factors can be deciphered, the basalt composition can be used to infer the evolution of the deep mantle/lithosphere at a given region [14-21]. In fact, abundant seamounts in the SCS provide a good opportunity to investigate the formation and evolution of the SCS.

This paper starts with a brief introduction to the basic concept and methodology for constraining lithospheric formation and evolution by studying volcanic rocks. It is followed by reviews on the study of Cenozoic volcanic rocks in the SCS and its surroundings. On the basis of temporal-spatial distribution of Cenozoic basalts in this region and their composition, we conceive possible dynamic models regarding the evolution of the SCS, which need to be evaluated in the future. Finally, a sampling and research design is presented that aims to solve the key questions outlined in the NSFC program on "The South China Sea Deep".

\section{Methods to constrain lithosphere evolution using volcanic rocks}

\subsection{Mantle melting and magma types generated}

Basaltic magma is formed by partial melting of adiabatically upwelled asthenosphere. To melt the mantle, the mantle 
solidus must be crossed by the adiabatic geotherm. In normal conditions, the dry mantle solidus is not intersected by oceanic or continental geotherms (Figure 2(a)). The intersection between geotherm and mantle solidus can be achieved in three ways [19]: (1) by increasing mantle temperature, as in the case of mantle plumes (Figure 2(b)), generating OIBtype magma and large igneous provinces; (2) by adiabatic upwelling of the asthenosphere subsequent to lithospheric extension (Figure 2(c)), forming MORB; and (3) by lowering the mantle solidus with the addition of volatiles (Figure 2(d)), as in the case of melting of a mantle wedge at convergent plates. The evolution of the SCS may involve both lithospheric extension and mantle plume activity. Therefore, Cenozoic volcanism in the SCS and its surroundings most likely produce MORB and OIB-type rocks. Nevertheless, the possibility of the SCS being a back-arc spreading center cannot be completely ruled out.

\subsection{Using volcanic rocks to constrain lithosphere evolution}

Basaltic magma is formed via polybaric fractional melting rather than by equilibrium melting. Basalts found at the surface are not the melting products of the upper mantle at a particular depth, but represent pooled melts derived from different levels by different melting extents $[16,19]$. In short, the melting behavior of the asthenospheric mantle can be depicted by the melting column concept [16].

When the temperature of the adiabatically rising asthenosphere exceeds that of solidus, it begins to melt. The pressure under which melting initiates is defined as $P_{0}$. With the asthenosphere rising, pressure decreasing, and melting degree increasing, the viscosity of the melt decreases significantly, promoting segregation of melts from the melting system. The pressure under which melts become segregated from the melting zone is defined as $P_{\mathrm{f}}$ [14]. Pooled magmas are derived from a depth interval (Figure 3(a),(b)), and the length of this melting interval reflects the range of melting pressure and the extent of melting. If the magma source is relatively homogeneous, magma composition mainly depends on mantle temperature and lithospheric thickness $[15,19]$. These two parameters correspond to the initial and final depths of melting, respectively. The initial depth of melting is dependent on mantle temperature; the higher the mantle temperature is, the greater the melting depth (Figure 3(c),(d)). The final depth of melting is controlled by the thickness of the lithosphere [15,18]. Like a "cap" over the asthenosphere, the rigid lithosphere prevents magma from further upwelling. As a consequence, the melting depth of the mantle under a thick lithosphere is greater than that under a thin lithosphere (Figure 3). The control of lithosphere thickness over the final depth of melting (i.e. the top of the melting column), is called the "lithosphere lid effect" [15,21,22]. According to this model, if the final depth of melting for a given basaltic magma is known, one can estimate the thickness of the overlying lithosphere.

MORB and mantle plume-derived continental flood basalts provide two end-member cases of mantle melting (Figure 3(c),(d)). As the mantle temperature is low $\left(T \mathrm{p} \sim 1300^{\circ} \mathrm{C}\right)$ at the mid-ocean ridge, the intersection between geotherm and mantle solidus can only be attained at a rather shallow level (Figure 3(c)). So the initial depth of melting is relatively

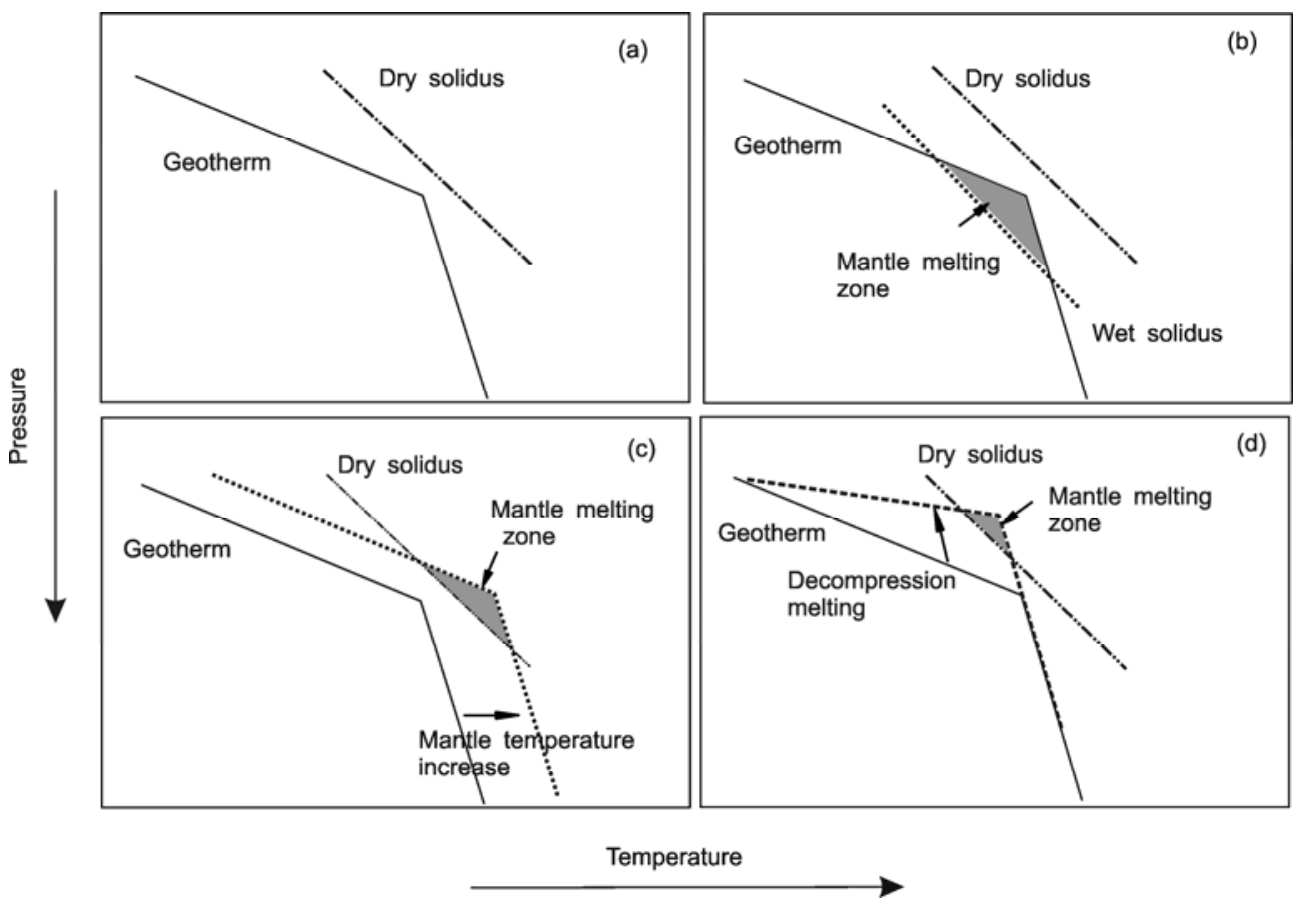

Figure 2 Three ways to melt the mantle [19]. 

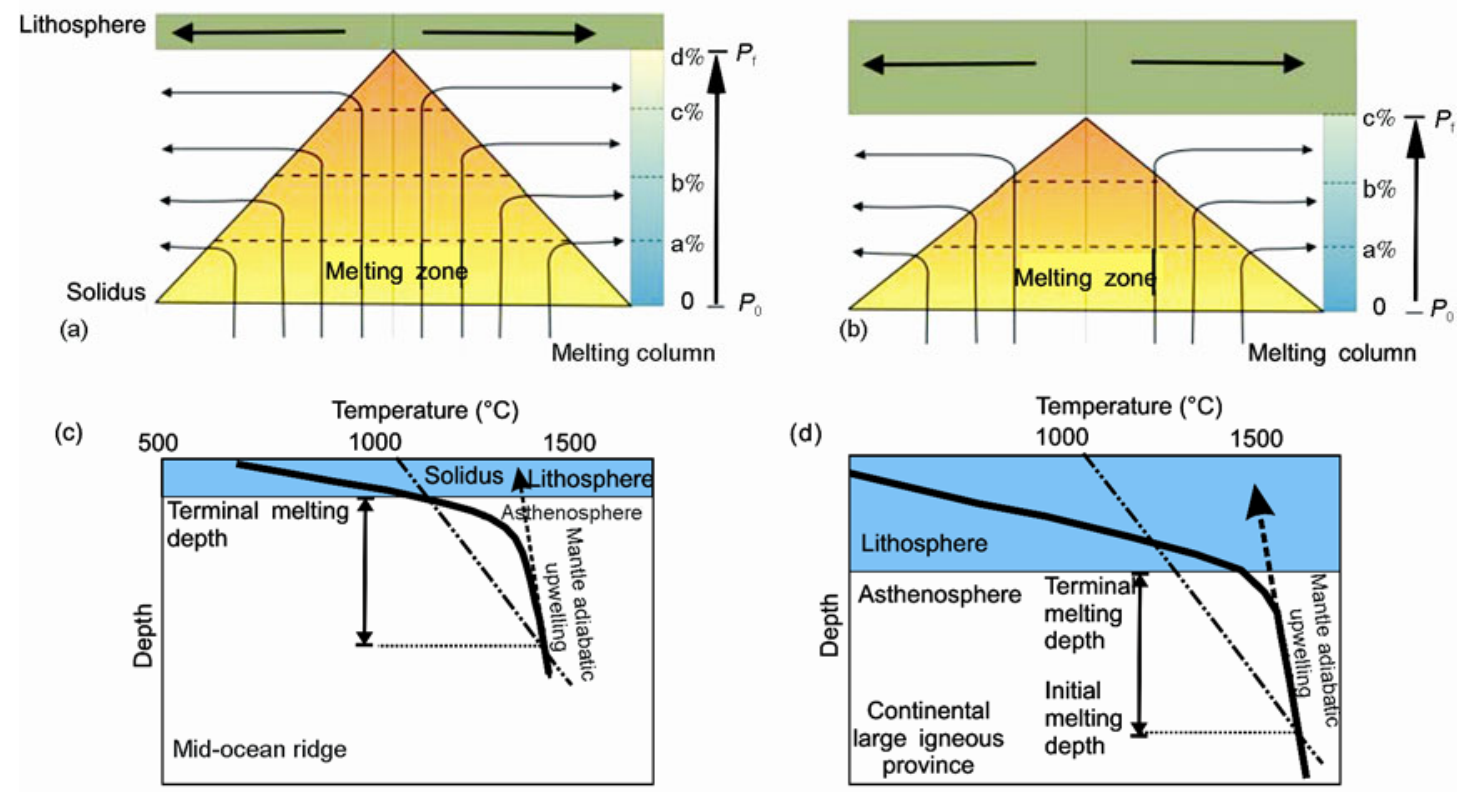

Figure 3 Schematic illustration of (a), (b) melting column model, and (c), (d) lithospheric lid effect (after [16,19]). (a) and (b) describe the melting phenomenon at various lithospheric thicknesses with the same mantle potential temperature. $P_{0}=$ initial pressure at which mantle starts to melt; $P_{\mathrm{f}}=$ final pressure at which mantle melts. The length of the arrow next to the melting column denotes the melting interval and is proportional to melting extent. At the given $P_{0}$, the thicker the lithosphere is, the higher the $P_{\mathrm{f}}$ is. A short melting interval means a small volume of melt generated and a low extent of melting. (c) and (d) depict the melting at different mantle potential temperatures and lithospheric thicknesses, corresponding to mantle melting at a mid-ocean ridge and in continental large igneous provinces.

small $(80 \mathrm{~km})$ [23]. As a result of the thin lithosphere, decompression melting of the mantle can happen up to a very shallow level. The long melting interval ensures a relatively high degree of melting. Therefore, MORB usually shows the spinel "fingerprint" (i.e. low rare earth element (REE) contents, and un-fractionated heavy rare earth elements (HREE)). In contrast, as a mantle plume has a high temperature $\left(T \mathrm{p} \sim 1500^{\circ} \mathrm{C}\right)$, the intersection between geotherm and mantle solidus takes place at a relatively deep level (garnet stability field) (Figure 3(d)). In this case, the initial depth of mantle melting is relatively deep $(>120 \mathrm{~km})$. As a result of the significant thickness of the overlying lithosphere, mantle decompression melting is confined to a deep level, resulting in a short melting interval (in the garnet stability field), and a garnet fingerprint. The generated melts therefore show a fractionated REE pattern. All these result in a lower extent of partial melting in the case of large igneous provinces than in the case of mid-ocean ridges. Humphreys and Niu [20] and Niu et al. [21] demonstrated that the geochemical composition of global OIBs is controlled by the thickness of oceanic lithosphere.

Therefore, as long as the initial and final melting depths of basalts emplaced at different times can be determined, one can obtain information (e.g. mantle temperature and lithosphere thickness) about deep processes. There are four ways to qualitatively or quantitatively determine the lithosphere thickness at the time of magma generation.

(i) Isotopic constraints. The lithospheric mantle, which is isolated from the convective asthenosphere, will develop a distinct isotopic composition as a result of isotope decay [24,25]. DePaolo and Daley [26] related the isotopic changes of late Cenozoic basalts in the southwestern United States to lithospheric thinning. They suggested that before or at the beginning of lithosphere thinning, the lithospheric mantle was the primary source of basalts. The asthenosphere gradually becomes the main source of basalts when the lithosphere thins. Therefore, the temporal change in isotope composition of basalts may reflect a change in lithospheric thickness. During the early period of lithosphere stretching $(\beta<1.2)$ in an area where no plume exists, the lithospheric mantle will melt first, probably assisted by the presence of volatiles. Nevertheless, over 95\% of melting takes place in the asthenosphere when the lithosphere and asthenosphere share similar melting behaviors, and the possibility that the lithosphere melts to generate magmas is very low $[19,23,27]$. When volatiles and enriched components in the lithospheric mantle are consumed and the lithosphere is still thicker than $100 \mathrm{~km}$, no melting of the asthenosphere occurs because the asthenosphere can only melt when the lithospheric thickness is less than $\sim 80 \mathrm{~km}$ [23]. This results in a magmatic hiatus during the transition in magma source from lithospheric mantle to asthenosphere in lithospheric thinning [19]. It is pointed out here that this method can only yield qualitative estimates on variation in lithospheric thickness.

(ii) Lithological constraints. Apart from source characteristics, basalt lithology is also controlled by temperature, pressure, and melting degree [28,29] and can be used to 
approximately constrain the melting depth of magmas. Anhydrous melting experiments on pyrolite show that compared with tholeiitic magma, alkali basalts or other more unsaturated magmas, are formed under pressure $>10 \mathrm{kbar}$ with melting extent $<15 \%$. Similar results have been obtained by melting experiments on peridotites (PHN1611) [29,30], which show that low pressure $(<10$ kbar) melting with a high melting fraction produces tholeiite with hypersthene and quartz norms; medium pressure melting ( $>12-15 \mathrm{kbar}$ ) generates alkali basalt with $\mathrm{Ne}$ norm $<10 \%$; and high pressure melting ( $>25 \mathrm{kbar}$ ) with melting extent $<10 \%$ produces nephelinite and melilitite with Ne norm $>10 \%$.

(iii) Rare earth element inversion. Because there is a considerable difference in the REE partition coefficients of spinel and garnet [31], REE composition is very sensitive to the stretching factor $(\beta)$. The spinel-garnet transition occurs at a depth interval of $60-80 \mathrm{~km}$ in the upper mantle $[32,33]$. When $\beta$ is $\sim 1.5-2$, the top of the melting column lies in this spinel-garnet transition zone. When $\beta<1.5$, melting will be confined to the garnet stability field, generating melts with strong garnet signature (high $\mathrm{Sm} / \mathrm{Yb}$ ) [15], and when $\beta>2$, the final melting depth is within the spinel stability field, generating melts with low Sm/Yb. Ellam [15], Fram and Lesher [22], and McKenzie and O'Nions [31] successfully estimated the formation depth of basalts using REE inversion methods. Nevertheless, there are some uncertainties associated with this method. (1) REE distribution coefficients used in REE inversion are obtained from experiments conducted under static conditions, whereas natural basalts are formed via dynamic decompression melting. In addition, partition coefficients of REE are dependent on the presence or absence of volatiles. For example, the pyroxene-melt partition coefficients of HREE are 5-200 times higher in the presence of $\mathrm{CO}_{2}$ than in the absence of $\mathrm{CO}_{2}$ [34]. (2) REE inversion assumes modes of minerals in the source, reactions and proportions of minerals entering melts. However, these parameters are mainly fixed artificially.

(iv) Major element constraints. Major element compositions of basalts correlate with their formation pressure. Some elements $\left(\mathrm{Na}_{2} \mathrm{O}, \mathrm{TiO}_{2}\right)$ behave incompatibly during melting and are mainly governed by melting degree. For instance, experiments show a negative correlation between $\mathrm{Na}_{2} \mathrm{O}$ content and melting temperature [28]. On the other hand, some other elements, such as $\mathrm{SiO}_{2}$ and $\mathrm{FeO}$, are pressure-sensitive, with high-pressure melts displaying high $\mathrm{FeO}$ and low $\mathrm{SiO}_{2}$ contents [28]. At a given pressure, melting degree has relatively little influence on the contents of these two elements. Therefore, major element composition can be used to constrain melting depth and melting degree. Klein and Langmuir [35,36] defined the local and global trend of $\mathrm{Na}_{2} \mathrm{O}-\mathrm{FeO}$ in $\mathrm{MORB}$, and proposed that variation of mantle potential temperature $(\Delta T \mathrm{p}=250 \mathrm{~K})$ is responsible for these trends. This interpretation suggests that the temperature of some mid-ocean ridge mantle, unaffected by mantle plumes, can be $250^{\circ} \mathrm{C}$ higher than normal mantle.
This does not sound reasonable, and indeed has been questioned by Niu and O'Hara [37] who criticized the crystallization correction method proposed by Langmuir's group. Niu and O'Hara related the global trend of MORB to the combined effect of mantle composition inheritance and enhanced melting process. On the basis of melting experiments with three peridotites (KLB-1, PHN1611, and Tinaquillo), Haase [17] obtained a linear regression between $\mathrm{SiO}_{2}$ and pressure, which is $P(\mathrm{GPa})=23.217-0.4381 \mathrm{SiO}_{2}(R=$ 0.878 ). These experimental results are supported by the positive correlation between basalt formation depths (calculated by average $\mathrm{SiO}_{2}$ content) and lithosphere age ( $\left.\leqslant 70 \mathrm{Ma}\right)$ observed in the Pacific and Atlantic oceans.

Many researchers have recently put forward melting models based on melting experiments with peridotites, in terms of major element compositions [14,16,23,35,38]. The most commonly used are the empirical model developed by Niu and Batiza [14] and the major element dynamic melting model of Langmuir et al. [16] (LKP). The LKP model has the following characteristics: (1) It only requires the contents of $\mathrm{MgO}, \mathrm{FeO}, \mathrm{Na}_{2} \mathrm{O}$, and $\mathrm{K}_{2} \mathrm{O}$, rather than compositions of all major elements. (2) The linear relationship established by many experiments between partition coefficients $\left(K_{\mathrm{d}}=C_{\text {mineral }}^{\mathrm{i}} / C^{\mathrm{i}}{ }_{\text {melt }}\right)$ and pressure, temperature, and composition, ensures the accuracy of data (for example, the average error of $K_{\mathrm{d}}^{\mathrm{Mg}}$ Ol/Melt is $5.3 \%$ ). So $K_{\mathrm{d}}$ as a function of pressure and temperature can be applied to different temperature-pressure conditions. (3) This model requires olivine as a residual mineral of the melting processes, a condition which is largely met in natural systems [29]. Wang et al. [39] and Zhang et al. [40] adopted the LKP model to calculate formation depths for Cenozoic basalts from the U.S. Basin and Range Province and from eastern China. Their estimated lithospheric thicknesses are very similar to those obtained by geophysical methods. Therefore, although the LKP model was established on the basis of MORB, it can be applied to continental intraplate basalts.

\subsection{Identification of mantle plumes using volcanic rocks}

There are five ways to identify mantle plumes [41,42]: (1) large scale crustal uplift prior to volcanism, (2) radiating dike swarm, (3) physical features of volcanism, (4) age progression along hotspot tracks or short duration of volcanism, and (5) chemical composition of magma, in particular involvement of components from the lower mantle. Because the SCS is covered with seawater, approaches (1) through (3) are difficult in practice. Therefore, we will focus here on approaches (4) and (5).

A volcanic chain produced by a mantle plume decreases in age in a direction opposite to plate movement. Mantle plume-derived basalt has OIB characteristics and higher $\mathrm{MgO}$ contents than MORB. The $\mathrm{Sr}-\mathrm{Nd}-\mathrm{Pb}$ isotopic composition should fall into the DMM-HIMU-EM1-EM2 mantle tetrahedron defined by OIB [43]. The isotopic composition 
of specific lava can be accounted for by the mixing of two or three of these four endmembers [44]. The complexity to this generalization is that magmas with OIB features are not necessarily the product of a mantle plume. For example, a basaltic seamount near the East Pacific Rise (EPR) and the Cenozoic basalt in eastern China have OIB-type features, but their origin has nothing to do with a mantle plume [45-47]. Therefore, an integrated approach is recommended to identify mantle plumes.

\section{Previous studies on volcanic rocks in the South China Sea and its surroundings}

\subsection{Temporal and spatial distribution of Cenozoic volcanism}

It has been inferred from studies on seafloor magnetic anomalies that the opening of the SCS started at $32 \mathrm{Ma}$ and ended at $15.5 \mathrm{Ma}$. Relative to this time frame of SCS spreading [1-3], volcanism in the SCS and its surroundings can be divided into three periods (Figure 4), i.e. prespreading, syn-spreading, and post-spreading.

(i) Pre-spreading ( $>32 \mathrm{Ma}$ ) volcanism. Volcanism of this period is mainly confined to the northern margin of the
SCS and to South China coastal areas (Figure 1), forming bimodal volcanic rocks in the Sanshui, Lianping, and Heyuan basins (Figure 4) [9]. K-Ar dates on these volcanic rocks range from 64 to $43 \mathrm{Ma}$ [48]. Rock types include basalt, andesite, dacite, trachyte, rhyolite, and tuff (Figure 5(a)). This bimodal magmatism may have resulted from double-layered convection in a magma chamber under an extensional environment associated with lithosphere thinning

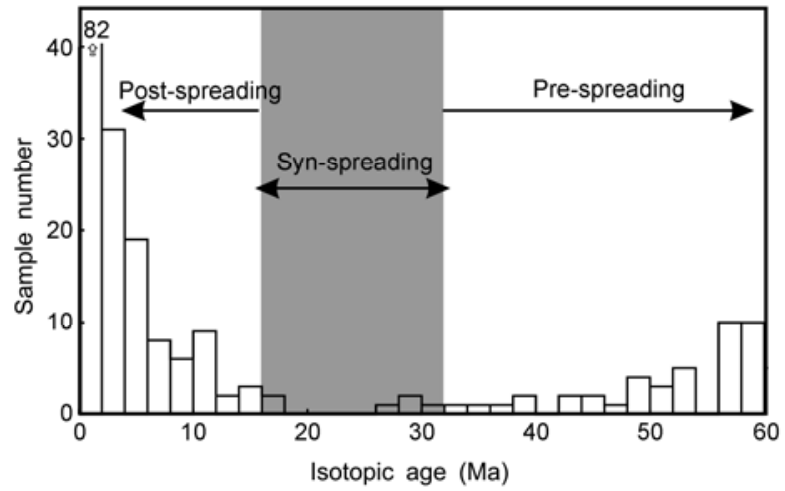

Figure 4 Age histogram of Cenozoic volcanism in the South China Sea and its adjacent regions shows three stages of magmatism. Data sources: [12,48-60]; Huang et al., unpublished data.
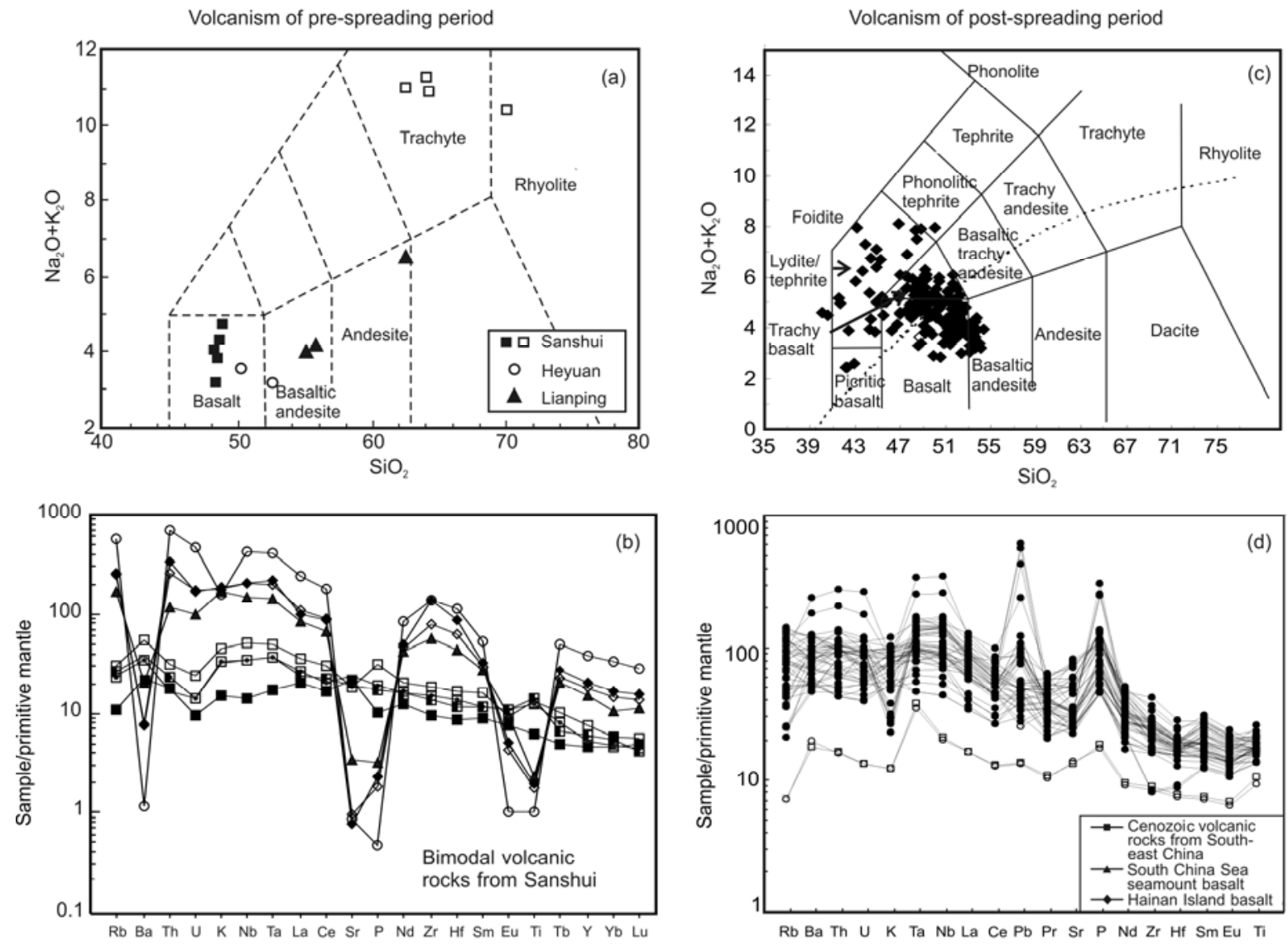

Figure 5 TAS diagram and trace element spidergram for Cenozoic volcanic rocks in the South China Sea and its surroundings. Data sources: [9,63,64]. Normalization values are after [65]. 
[9]. In addition, dispersed Oligocene volcanic rocks (K-Ar ages 45-17 Ma; China Nanhai East Oil Company information) occur in the Pearl River Mouth basin and eastern Guangdong province. Zou et al. [49] studied trace element and $\mathrm{Sr}-\mathrm{Nd}-\mathrm{Pb}$ isotope composition of basalt from the Pearl River Mouth basin and found their Dupal $\mathrm{Pb}$ isotopic anomaly. Volcanic pipes of 35 Ma occur in Qiling, eastern Guangdong Province. These pipes carry a large amount of mantle-derived xenoliths, which have attracted much attention for studying the thermal state, lithospheric structure, and processes of the upper mantle [10,61,62].

(ii) Syn-spreading (32-16 Ma) volcanism. So far, no report is available on seafloor basalts emplaced in the synspreading period. Information about volcanism in this period mainly comes from early studies on seafloor magnetic anomalies. Because it is generally accepted that the formation of seafloor magnetic anomalies is related to creation of new oceanic crust during oceanic ridge spreading, the magnetic anomaly observed in the SCS $[1,2]$ therefore can be regarded as a reflection of syn-spreading volcanism. The spatial distribution of the seafloor magnetic anomaly is roughly equivalent to that of magmatic activities [11] (Figure 1), and the forming time of these anomalies (i.e. late Oligocene to mid Miocene) is roughly the same as that of the volcanism. The key to test the timing and process of the SCS spreading is to obtain volcanic rocks emplaced during this period. Deep drilling and dredging at specific locations (e.g. at normal faults) are the approaches to make a breakthrough.

Syn-spreading magmatic activities in the surrounding areas of the SCS are very rare (Figure 4). So far, the only reported instances are $\sim 20 \mathrm{Ma}$ basalts in Jiucaidi and Puzhai in eastern Guangdong Province (Huang et al., unpublished data).

(iii) Post-spreading (<16 Ma) volcanism. E-W oriented seamounts in the central sub-basin, NE-SW oriented seamounts in the southwest sub-basin and those scattered on the seafloor were likely formed in this period (Figures 1 and 4). Wang et al. [50] were among the first to report K-Ar and Ar-Ar ages of three dredged samples from seamounts in the SCS, which are 13.8, 9.9, and 3.5 Ma, respectively. K-Ar dating of the samples dredged from the north slope of East Reed bank yield very young ages of 2.7-0.4 Ma [51]. Yan et al. [52] reported K-Ar ages of basalts from the same area which range from 7.91-3.80 Ma.

Recently, Han [53] reported that some samples recovered from the southwest sub-basin show MORB-like composition and K-Ar ages of approximately 11.5-3.4 Ma. These ages are significantly younger than the commonly accepted terminal age of seafloor spreading in the SCS. If these data are reliable, the spreading history of the SCS needs to be revised. However, these ages may be underestimated due to $\mathrm{K}$ introduction during seawater alteration. Clearly, further work is needed to reconcile this apparent contradiction.
Post-spreading magmatism is widespread in the surrounding areas of the SCS, including Hainan Island, Leizhou Peninsula, Thailand, and Vietnam (Figure 1). The easy accessibility of these young continental basalts has ensured detailed studies on the magmatism of this period. Volcanic eruptions of this period had two stages [63]. Early stage volcanism is characterized by large scale lava flooding along major extensional fractures, forming quartz and olivine tholeiites, which constitute the main rock sequences. The later stage features scattered volcanic center eruptions, forming alkali olivine basalt and basanite, some of which contain upper mantle/lower crust-derived xenoliths.

Over $7000 \mathrm{~km}^{2}$ of late Cenozoic volcanic rocks are exposed in the Leiqiong area. Among the 86 compiled ages of these rocks [54-57], 54 are Pleistocene, 14 are Pliocene, 15 are Miocene, 2 are Oligocene, and 1 is Eocene (Figure 4). Alkali basalts (K-Ar ages of 5.9-2.4 Ma) from the Beibu Gulf basin on the northern margin of the SCS also belong to this stage of magmatism [58].

Late Cenozoic basalts were also emplaced west of the SCS, such as in southern Vietnam, southern Laos, the Khorat plateau in southern Thailand, and southeastern Cambodia. Early K-Ar and fission track dating of these basalts yield an age range of 12-0 Ma [59]. Lee et al. [12] dated 41 volcanic rocks from Vietnam using the Ar-Ar technique and identified three magmatic periods: $15.5-10.5 \mathrm{Ma}$, during which quartz tholeiite was erupted; 8-5 Ma, during which erupted basalts gradually shift from quartz tholeiite to olivine tholeiite; and the Pliocene-Quaternary, during which the emplaced magmas are mainly alkaline-strong alkaline basalts. The age of the Vietnamese basalts is virtually identical to that of basalts in the Hainan Island-Leizhou Peninsula area. The oldest age of this period of magmatism is roughly the same as the terminal timing of SCS spreading. Certainly, this cannot be just a coincidence. It reflects either the migration of the magmatic locus from an oceanic ridge to the edges of surrounding plates, or a temporal and spatial expression of mantle plume activities in this area.

\subsection{Geochemistry of volcanic rocks in the South China Sea and surroundings}

In the TAS plot (Figure 5), pre-spreading magmas show a bi-modal distribution, consisting of tholeiitic basalt and trachyte. Their Sr isotopic ratios vary between 0.705 and 0.711 , and $\varepsilon_{\mathrm{Nd}}$ ranges from 6 to -5 . In contrast, the post-spreading magmas are basalt, basaltic andesite, and basaltic trachyte. Some samples fall into the fields of basanite and alkali basalt, but most of the samples straddle the transition between alkali and sub-alkaline lavas (Figure 5(c)). These basalts are enriched in large ion lithophile elements (LILE), high field strength elements (HFSE), and light rare earth elements (LREE), and have positive $\mathrm{Ta}$ and $\mathrm{Nb}$ anomalies. The incompatible element distribution patterns of these basalts resemble those of typical OIB (Figure 5(d)). 
Two main features are noted from the isotope correlation diagrams (Figure 6) for post-spreading volcanic rocks:

(1) They delineate binary mixings between DMM and EM2 components in ${ }^{207} \mathrm{~Pb} /{ }^{204} \mathrm{~Pb}$ vs. ${ }^{206} \mathrm{~Pb} /{ }^{204} \mathrm{~Pb}$ and ${ }^{208} \mathrm{~Pb} /$ ${ }^{204} \mathrm{~Pb}$ vs. ${ }^{206} \mathrm{~Pb} /{ }^{204} \mathrm{~Pb}$ diagrams (Figure 6). Likewise, the negative correlation between ${ }^{143} \mathrm{Nd} /{ }^{144} \mathrm{Nd}$ and ${ }^{206} \mathrm{~Pb} /{ }^{204} \mathrm{~Pb}$, and the positive correlation between ${ }^{87} \mathrm{Sr} /{ }^{86} \mathrm{Sr}$ and ${ }^{206} \mathrm{~Pb} /$ ${ }^{204} \mathrm{~Pb}$, also point to mixing between DMM and EM2 components. Similar isotopic characteristics are observed for late Cenozoic basalts from the Taiwan Strait [68,69], Vietnam [70], Thailand [71], and Australia [46].

(2) The post-spreading basalts show higher ${ }^{87} \mathrm{Sr} /{ }^{86} \mathrm{Sr}$, ${ }^{207} \mathrm{~Pb} /{ }^{206} \mathrm{~Pb}$, and ${ }^{208} \mathrm{~Pb} /{ }^{206} \mathrm{~Pb}$ ratios at a given ${ }^{206} \mathrm{~Pb} /{ }^{204} \mathrm{~Pb}$ ratio compared with MORB, pointing to a Dupal isotopic anomaly (Figure 6) [64,72].

\section{Preliminary understanding on the opening and evolution of the South China Sea}

\subsection{The opening of the South China Sea}

Volcanic samples available so far from the SCS basin are mostly post-spreading OIB-type alkali and tholeiitic basalts. The only exception is several MORB-like samples recovered from the southwest sub-basin [53]. However, the exact age and geological significance of these samples require further studies. The lack of syn-spreading samples hampers the placing of constraints on the opening of the SCS.

Mesozoic mafic magmatism occurred in the South China interior, for example, in southern Jiangxi, southern Hunan, and western Fujian provinces [73,74]. Toward the late Mesozoic-early Cenozoic, magmatism migrated to the southeastern and southern margins of South China, forming the Sanshui, Lianping, and Heyuan volcanic basins and that of the Pearl River Mouth $[9,48]$. Southward migration of the rifting continental margin may have triggered the opening of the South China Sea [9].

The most popular model for the opening of the SCS is the continental excursion model proposed by Tapponnier et al. [75], in which left-lateral movement of the AilaoshanRed River shear zone as a result of the collision of India with Asia ultimately led to the opening of the SCS. However, Chung et al. [76] argued, on the basis of the highly potassic magmas that were emplaced from ca. 40 to $30 \mathrm{Ma}$, that intraplate extension took place prior to extrusion activity (ca. 27-22 Ma). These authors therefore suggested that seafloor spreading of the SCS that began ca. $30 \mathrm{Ma}$, could have accounted for-rather than stemmed from-the initiation of the Ailao Shan-Red River shear zone.

The peridotite-pyroxenite xenoliths entrained in the $\sim 35$ Ma volcanic pipe at Qilin delineate a relatively high geotherm [62]. Moreover, the trace element composition of peridotite xenoliths suggests a polybaric melting experienced by the upper mantle in this region [10], indicating the peak extension of the lithosphere during the early Cenozoic. In addition, $\mathrm{Yb}$ contents in 40-50 Ma magmas are higher than those in $\sim 20$ Ma basalts (Figure 7), consistent with a gradual increase in origin depth of magmas, probably due to waning of regional extension towards the mid-Cenozoic. All this suggests that the extension of the South China continental
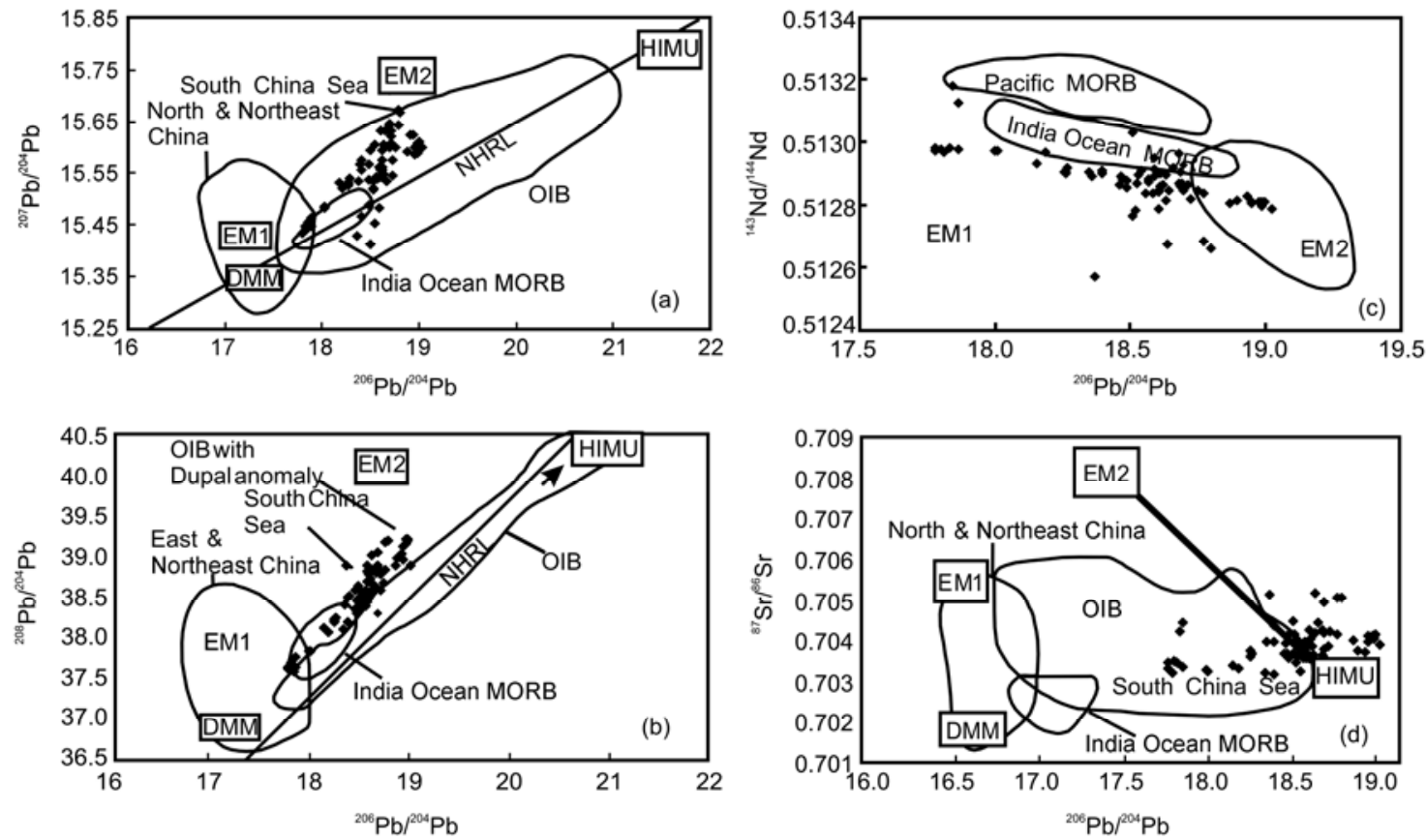

Figure 6 (a) ${ }^{207} \mathrm{~Pb} /{ }^{204} \mathrm{~Pb}$ vs. ${ }^{206} \mathrm{~Pb} /{ }^{204} \mathrm{~Pb}$; (b) ${ }^{208} \mathrm{~Pb} /{ }^{204} \mathrm{~Pb}$ vs. ${ }^{206} \mathrm{~Pb} /{ }^{204} \mathrm{~Pb}$; (c) ${ }^{143} \mathrm{Nd} /{ }^{144} \mathrm{Nd}$ vs. ${ }^{206} \mathrm{~Pb} /{ }^{204} \mathrm{~Pb}$; (d) ${ }^{87} \mathrm{Sr} /{ }^{86} \mathrm{~S}$ vs. ${ }^{206} \mathrm{~Pb} /{ }^{204} \mathrm{~Pb}$ for the post-spreading volcanic rocks. Data sources: [9,64,66,67]. 


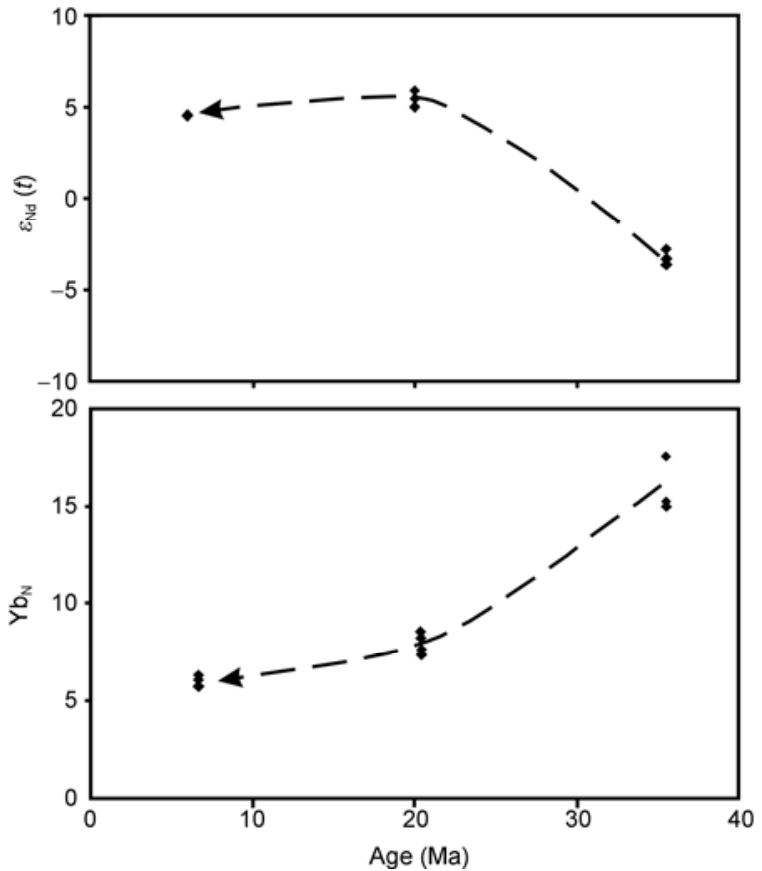

Figure 7 Variation of $\varepsilon_{\mathrm{Nd}}$ and $\mathrm{Yb}$ with time for the Cenozoic volcanic rocks in the South China Sea and its surroundings.

margin lasted from $40-50$ to $20 \mathrm{Ma}$, in good accordance with the estimate (45-25 Ma) from sedimentation rate and extent [77].

According to drilling cores from the Pearl River Mouth and Northern Bay basin and from modeling, Clift et al. [77] suggested a relatively small viscosity of the lower crust of the South China continental margin. They thus proposed that rifting of the south China continental margin was related to a decrease in lithospheric strength, although Yan et al. [11] have a different opinion.

\subsection{Hainan mantle plume and its link with the opening of the South China Sea}

Seismic tomography by Lebedev and Nolet [5], and Montelli et al. [6] shows a virtually vertical low velocity structure beneath Hainan Island, which extends as deep as $1900 \mathrm{~km}$. This suggests that the Hainan plume may have been derived from the lower mantle. Zhao [78] and Lei et al. [7] came to a similar conclusion and regarded the Hainan mantle plume as one of 12 plumes that originated from the core-mantle boundary. Is there petrologic evidence for the Hainan mantle plume?

On the basis of olivine-melt equilibrium, Yan and Shi [8] inferred that the potential temperature $(T \mathrm{p})$ of the mantle from which the SCS Cenozoic basalts were derived is $1661^{\circ} \mathrm{C}$, significantly higher than that of the normal mantle. Similar results have been reached by Wang et al. [79] who identified magnesian olivine $\left(\mathrm{FO}_{90.7}\right)$ phenocrysts in late Cenozoic Hainan basalts. The high magnesian olivine points to an unerupted picritic melt $(\sim 16 \%-18 \% \mathrm{MgO})$, generated by a hot mantle with $T \mathrm{p}$ of $1541^{\circ} \mathrm{C}$. Hoang and Flower [70] studied P-T melting conditions for Cenozoic basalts from Vietnam. They obtained a melting temperature of 1400$1470^{\circ} \mathrm{C}$ and pressure of $<0.5-4 \mathrm{GPa}$ under dry conditions and a melting temperature of $1350-1450^{\circ} \mathrm{C}$ and pressure of $<1.5-3.5 \mathrm{GPa}$ under water-undersatured conditions. Although different in detail, all these results reveal relatively high potential temperatures for the mantle beneath the SCS. In addition, their OIB type geochemistry does not contradict a mantle plume model. For instance, in a plot of Ta/Hf vs. Th/Hf (Figure 8), volcanic rocks from the SCS and its surroundings plot within the area for plume-derived basalts.

Different views exist about the origin of the EM2-type Dupal isotope anomaly. Hart [72] initially claimed that the Dupal anomaly exclusively occurs in the southern hemisphere. However, later studies have shown that the Dupal anomaly also occurs in the northern hemisphere, with the SCS and its surroundings as type examples [63,64,80,81]. It has been suggested that the presence of the Dupal anomaly in the northern hemisphere is due to the location of South China in the Gondwana supercontinent in the southern hemisphere [81]. Paleomagnetic studies show that in the late Paleozoic, Southeast China may have migrated northward [82]; the Dupal anomaly in basalts from the SCS and its surroundings may therefore have inherited values from the Gondwana continent. Such an interpretation involves the coupling of the supercontinent with the convective mantle,

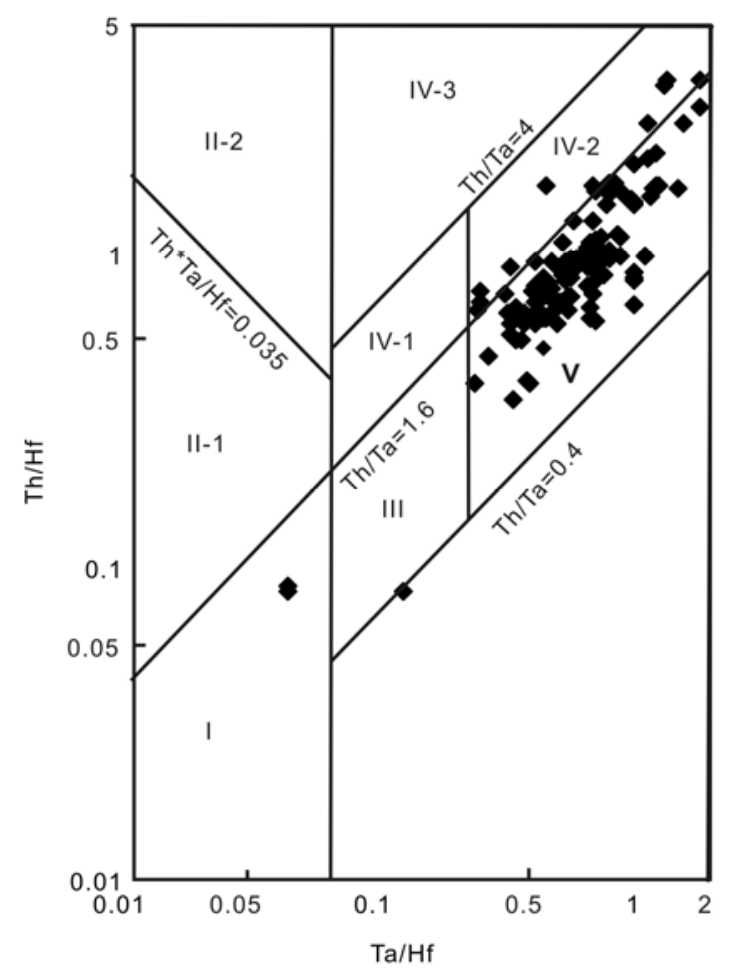

Figure $8 \mathrm{Ta} / \mathrm{Hf}$ vs. Th/Hf for the post-spreading volcanic rocks. I, NMORB; II, convergent margin: II-1, OIB; II-2, continental arc and island arc basalts; III, Oceanic island and seamount basalts, TMORB and EMORB; IV, Intraplate; V, mantle plume. Data sources as in Figure 6. 
from which basalts with the Dupal anomaly are derived. However, there is no evidence for such a coupling because the formation and rifting of the super-continent generally take place on a lithospheric scale. For instance, the North China Block was once a part of the Laurencia continent in the northern hemisphere $[82,83]$, but the Cenozoic basalts from this region also display relatively higher ${ }^{208} \mathrm{~Pb} /{ }^{204} \mathrm{~Pb}$ and ${ }^{207} \mathrm{~Pb} /{ }^{204} \mathrm{~Pb}$ at given ${ }^{206} \mathrm{~Pb} /{ }^{204} \mathrm{~Pb}$, delineating a Dupal anomaly.

The genesis of the Dupal anomaly may be related to recycling of continental crust or lithospheric mantle in the basalt source [64]. The enriched lithospheric mantle beneath South China commonly displays HFSE depletion [10,84], in striking contrast with the HFSE enrichment in Cenozoic basalts from this area. Given the fact that the lithosphere is relatively thin underneath the SCS [85], and it may have been thinned during the period of eruption [2], it is suggested that the EM2 component in basalts from the SCS and its surroundings is not related to recycling of lithospheric mantle.

Because of the extremely low concentration of $\mathrm{Pb}$ in the depleted mantle [86], $\mathrm{Pb}$ isotopes are the most sensitive tracer in identifying crustal components. White and Dupre [87], and Mukasa et al. [88] suggested that the Dupal anomaly is related to the involvement of crustal components by subduction, on the basis of $\mathrm{Pb}$ isotopic composition. This has been adopted by Zhu and Wang [54], and by Zhang et al. $[66,89]$, to account for the $\mathrm{Pb}$ isotopic systematics of basalts from the Lei-Qiong area. It is likely that subduction-related components in the mantle source are related to recycled crustal components recovered by mantle plumes. Using ${ }^{230} \mathrm{Th} /{ }^{238} \mathrm{U}$ of the young basalts from Hainan island ( 9000 a), Zou and Fan [81] estimated the upwelling rate of the Hainan mantle plume to be $<1 \mathrm{~cm} / \mathrm{a}$, significantly lower than that for the Hawaii plume (10-30 cm/a) [90]. If the small upwelling rate is related to a waning mantle plume, this may imply a waning stage of the Hainan mantle plume during the late Cenozoic.

If the Hainan mantle plume does exist, a relevant issue is whether plume activity was responsible for the opening of the SCS. Because the duration of the Hainan plume activity is poorly constrained, no clear answer is available at this stage.

Over $90 \%$ of continental margins in the world are volcanic rifted margins, which have the following features: large igneous province, high velocity lower crust (HVLC) in the continent-ocean transition, and a seaward-dipping reflector series (SDRS) [91]. From the limited distribution of volcanism and available seismic profiles in the northern margin of the SCS, the South China continental margin does not share these characteristics, perhaps implying that the opening of the SCS was not caused by a mantle plume [52]. Likewise, the fact that all the OIB-type basalts were emplaced during the post-spreading stage, even if these rocks resulted from melting of the Hainan plume, suggests that the mantle plume may not be responsible for the opening of the SCS. The uncertainty with such a conclusion includes the following: (1) the volcanic rifted margin may not be exclusively related to a mantle plume [92]; and (2) mantle plume-derived basalts do not always have OIB-type composition, especially in the circumstance of ridge-mantle interaction (see the following).

Two dynamic models are conceived to account for the temporal-spatial distribution of Cenozoic basalts in the SCS and its surroundings (Figure 4).

(1) The opening of the SCS and the Hainan plume activity are two independent events. During the spreading of the SCS, magmas were largely derived by decompression melting of convective mantle. As a result of the compression of surrounding regions created by the spreading of the SCS, magmatism is largely confined in the SCS basin. After the spreading of the SCS, the compressional stress on the surrounding regions was released, triggering the melting of the upper mantle and eruption of basalts in the SCS and its surroundings.

(2) All the Cenozoic magmas in the SCS and its surroundings were related to a mantle plume. During the spreading of the SCS, as a result of ridge suction [13], the mantle plume flowed towards the ridge of the SCS (Figure 9), generating basalts in the SCS basin. After the spreading of the SCS, ridge suction was no longer exerted on mantle flow. Consequently, plume-derived basalts are spread out in the SCS and its surroundings. In this model, the tectonic setting of the SCS is similar to that in Iceland where a mantle plume and mid-ocean ridge coincide. An inevitable consequence is ridge-mantle plume interaction, during which magmas generated are not typical MORB, but intermediate between MORB and OIB. Moreover, the generated basalts may display spatial variation in composition (Figure 9); a prediction can be tested in future studies.

\section{A sampling and research design}

It is clear that the widespread volcanism in the SCS and its surroundings can provide important information about the evolution of the SCS and related deep dynamic processes. However, the affinity, emplacement age, and related genetic processes of these rocks still remain poorly characterized. This may be due to the following reasons:

(1) It is very difficult to obtain volcanic samples from the SCS. Dredged seamount samples are very rare and precious and can yield emplacement age and geochemical affinity; but lack of systematic sampling does not allow definition of the temporal and spatial variation of magmatism associated with seafloor spreading, rendering it difficult to constrain the formation of the SCS.

(2) Previous studies did not pay much attention to the link between petrogenetic studies and deep dynamic processes. Most existing studies focused on documentation of 


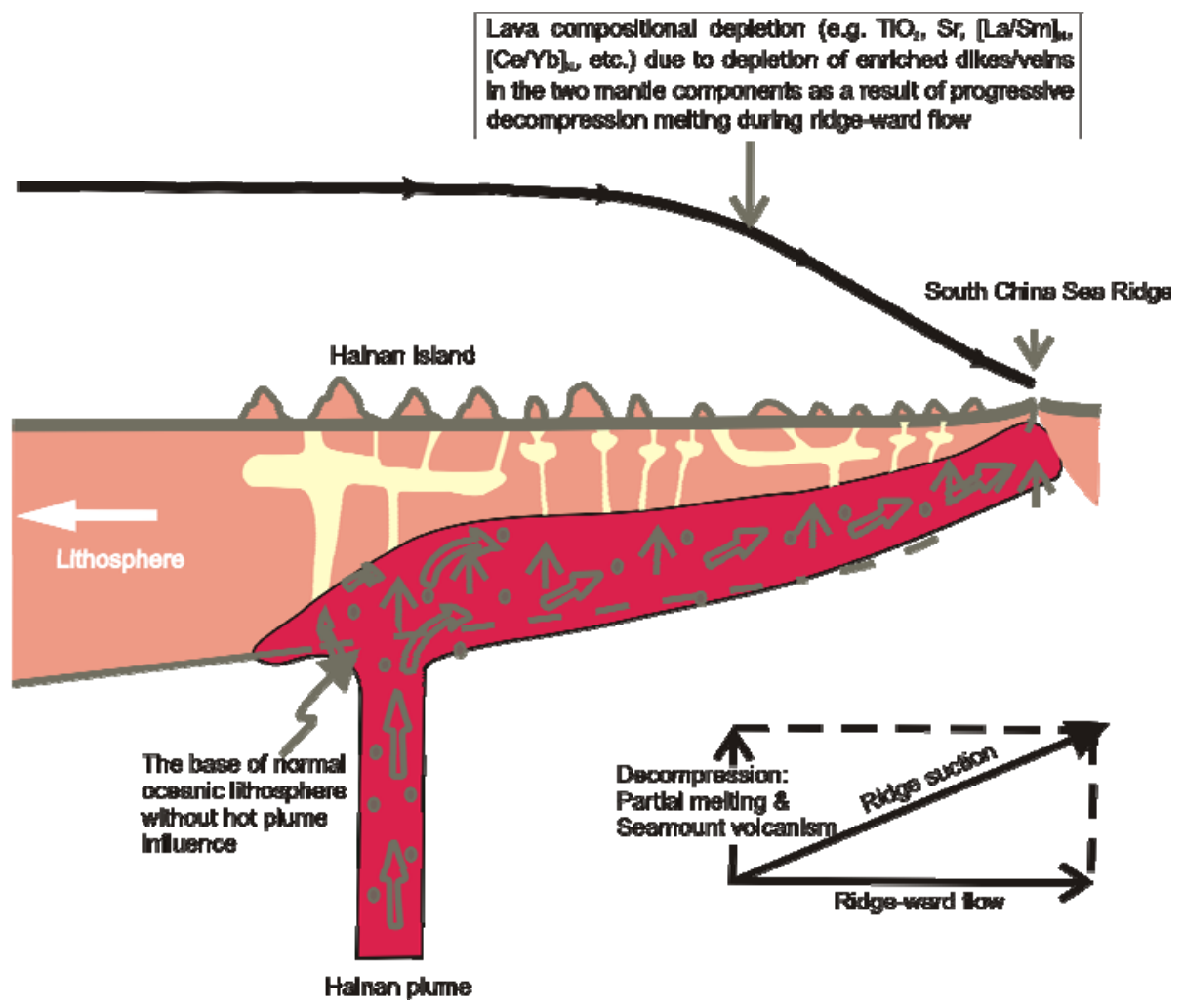

Figure 9 The ridge suction model (modified after [13]) to account for the temporal distribution of Cenozoic volcanic rocks in the South China Sea and its surroundings.

the age and geochemistry of individual samples, which are not sufficient to decipher the relationship between mantle processes and the opening of the SCS.

To mitigate these shortcomings, we need to solve the sampling problem first. In considering useful applications for the IODP drilling project, we suggest organized dredging of seafloor samples under the NSFC program on the SCS. We suggest the northern area of the central sub-basin as the main target area (Figure 10). Following the dredge plan illustrated in Figure 10, together with some near surface drilling, we expect to obtain seamount samples along the A-B profile in the central sub-basin, and additional samples along the $\mathrm{C}-\mathrm{D}$ profile, perpendicular to A-B. This sampling plan is based on the following considerations: (1) The seamounts along A-B may represent the spreading ridge of the SCS, therefore probably recording the termination age of the SCS spreading, while the northern margin of the targeted area could preserve the oldest oceanic crust of the SCS from which the timing of the initiation of SCS spreading can be deduced; (2) the samples along C-D may register the evolution of the SCS; and (3) the targeted area has many seamounts close to sea level, which ensures relatively easy dredge sampling.

\subsection{Spreading history of the South China Sea}

If MORB samples can be obtained through systematic

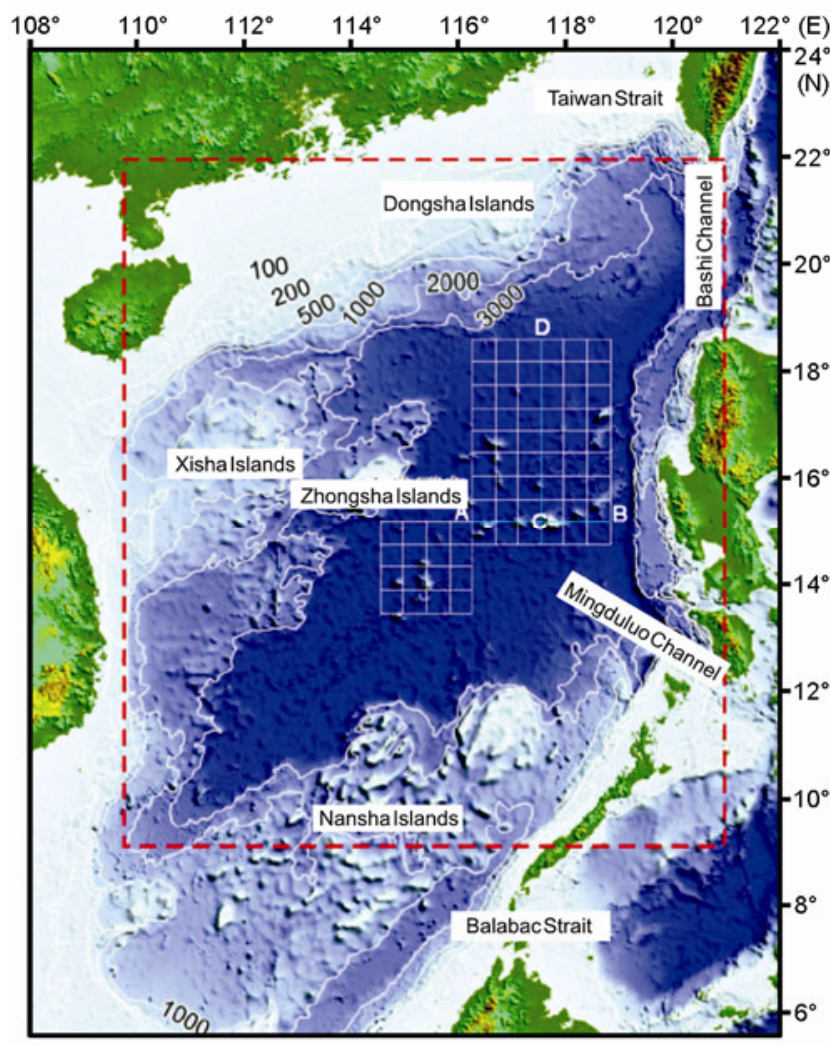

Figure 10 Proposed plan for dredging of seafloor samples in the South China Sea. 
dredging, high precision Ar-Ar dating of samples from the $\mathrm{C}$-D profile will enable us to define the initiation and termination age of SCS spreading. These data are the key to construct a SCS evolution model and can be compared with the results of magnetic and seismic studies. In addition, these chronological data and the size of the ocean basin can be used to estimate the ridge spreading rate. It has been demonstrated that MORB composition is dependent on the rate of ridge spreading [18], so the composition can be used to estimate this rate.

Given the deep SCS basin and very thick sediments on the seafloor, the accessibility of MORB crust remains uncertain. The dredging of seamounts most likely will yield post-spreading OIB type magma samples. These kinds of samples (especially those from the north-south C-D profile, Figure 10) can be used to indirectly constrain the evolution of the SCS. Most volcanic rocks from the SCS are derived from the convective mantle [64]. For a given magma source, the composition of erupted lavas is dependent on melting depth. Determination of initial and final depth of melting using basalt geochemistry helps to infer the thickness of the lithosphere at the time of volcanic eruption. This exercise can test whether there is a gradual increase in lithospheric thickness from $\mathrm{C} \rightarrow \mathrm{D}$ (Figure 11), as required by the proposed SCS spreading model. It has been demonstrated that the thickness of generated oceanic crust correlates with its formation age [93-97]. Therefore, one can calculate the formation age of oceanic crust using the estimated lithospheric thickness, which in turn can be used to estimate the initiation and termination ages of SCS spreading.

\subsection{Petrologic verification of the Hainan mantle plume}

Systematic dredging of seafloor and seamount samples can also help us to investigate petrologic evidence for whether the Hainan plume exists, and by inference, the role played by the Hainan plume during SCS spreading. Research can be undertaken in the following three aspects.

(1) Ar-Ar dating of the samples dredged from the linear seamount along the A-B profile can help to determine whether there is age progression from $\mathrm{A} \rightarrow \mathrm{B}$. A linear correlation between emplacement age and volcano distance, as recognized in the Hawaii case, is strong evidence for the existence of mantle plumes.

(2) Mantle plumes have higher potential temperature $\left(\sim 200^{\circ} \mathrm{C}\right.$ higher) compared with the normal mantle. Experiments show a relationship between the composition of primary magmas and mantle potential temperature, so if the composition of primary melts is determined, the mantle potential temperature can be estimated. The bulk composition of volcanic rocks, which represents pooled magmas and results from magma mixing and fractional crystallization,

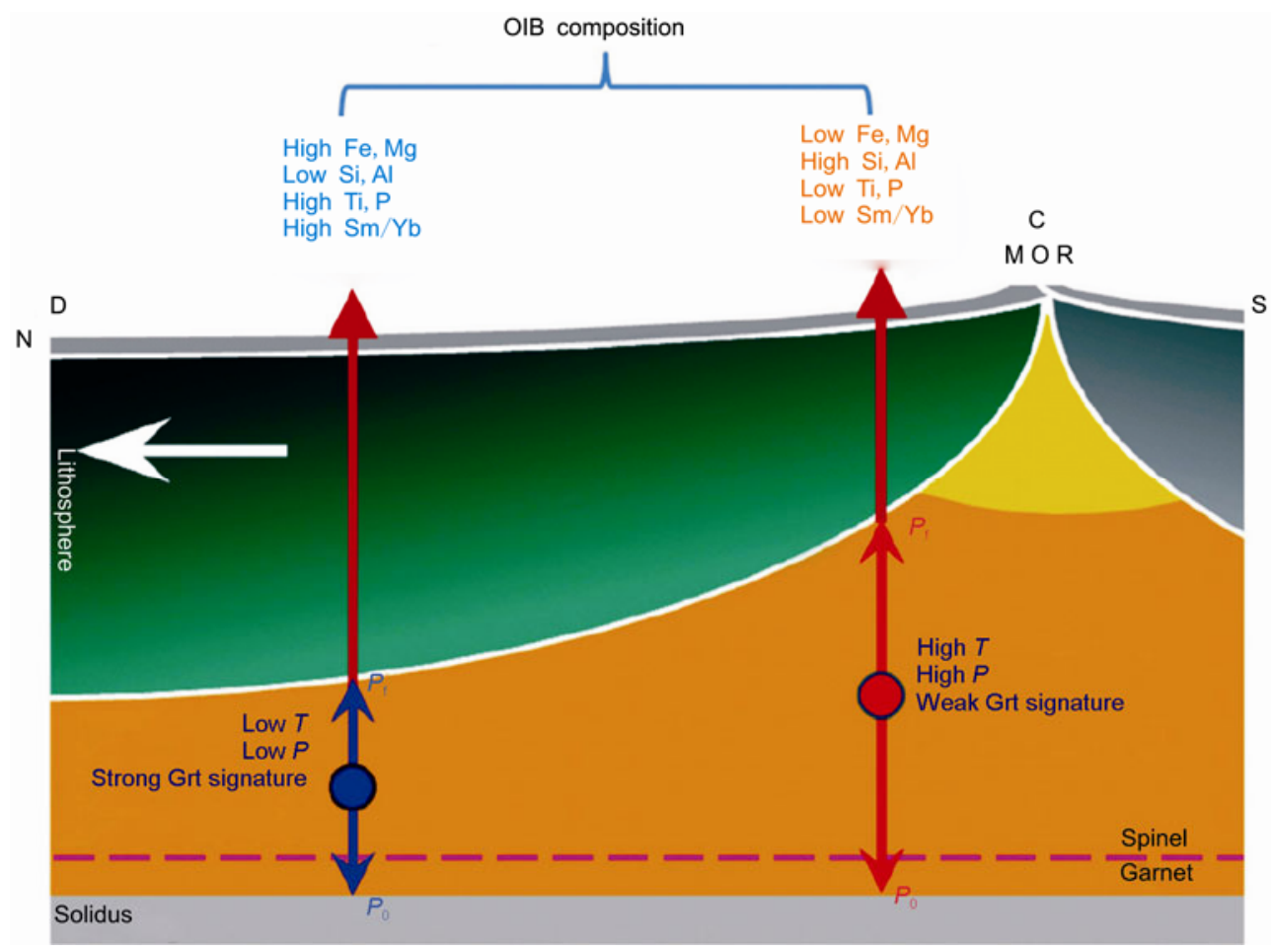

Figure 11 Schematic illustration of inferred lithospheric architecture along the C-D profile in Figure 10 (modified after [21]). C corresponds to the position of the youngest ridge material in the South China Sea. According to the SCS spreading model, the thickness of the lithosphere increases from C $\rightarrow$ D. The composition of post-spreading basalts is dependent on mantle potential temperature and lithospheric thickness. Given the relationship between the thickness of generated oceanic crust and its formation age, one can calculate the formation age of the oceanic crust using the estimated lithospheric thickness, which in turn can be used to estimate the initial and terminal ages of SCS spreading. 
cannot preserve the composition of primary magmas [98,99]. Compared with the bulk rock composition, melt inclusions in olivines have the following distinct advantages [100]: (1) Olivine crystallizes first from primary melts, so olivine with high Fo could trap melt inclusions that preserve the composition of primary melts [99]. (2) The very low concentration of incompatible elements in olivine renders it easy to estimate the trace element composition of melt inclusions. It is thus highly recommended to undertake melt inclusion studies on olivine phenocrysts recovered from the SCS seafloor samples.

(3) It is necessary to undertake detailed petrological and geochemical studies on volcanic rocks from the SCS. Using lithoprobe and isotopic tracing techniques, one can understand the melting mechanism and define source characteristics, in particular, define the relative contributions to magma genesis from the asthenosphere, mantle plume, lithosphere mantle, and crust. Comparison of these data with typical known plume-related basalts can yield further constraints on the issue of whether a mantle plume exists in the SCS.

\subsection{Ridge-mantle plume interactions}

If both seafloor spreading and a mantle plume were operative in the SCS, an inevitable consequence is ridge-mantle plume interactions. The magmas generated in this circumstance may not be typical MORB. In addition, ridge suction may result in regular variation in basalt chemistry, as illustrated in Figure 9. The verification of this model again requires systematic sampling across the transect linking the plume core and the SCS ridge.

At this stage, the hypotheses regarding the evolution of the SCS outnumber the conclusions we can reach. This situation will certainly improve with the operation of the "South China Sea Deep" NSFC program.

We thank Prof. Wang P.X. for inviting us to write this paper. Prof. Niu Yaoling and an anonymous referee provided very constructive reviews that led to significant improvement of the manuscript. This work was supported by the National Natural Science Foundation of China (91128203), the CAS/SAFEA International Partnership Program for Creative Research Teams (KZCX2-YW-Q04-06), and the National Basic Research Program of China (2011CB808906).

1 Taylor B, Hayes D E. Origin and history of the South China Sea basin. In: Dennis E, Hayes D E, eds. The Tectonic and Geologic Evolution of South Eastern Asian seas and islands. AGU Geophys Monogr, 1983. 23-56

2 Briais A, Patriat P, Tapponnier P. Updated interpretation of magnetic anomalies and seafloor spreading stages in the South China Sea: Implications for the Tertiary tectonics of Southeast Asia. J Geophys Res, 1993, 98: 6299-6328

3 Kido Y, Suyehiro K, Kinoshita H. Rifting to spreading process along the northern continental margin of the South China Sea. Mar Geophys Res, 2001, 22: 1-15

4 Hsu S K, Yeh Y C, Doow B, et al. New bathymetry and magnetic lineations identification in the northernmost South China Sea and their tectonic implications. Mar Geophys Res, 2004, 25: 29-44
5 Lebedev S, Nolet G. Upper mantle beneath southeast Asia from S velocity tomography. J Geophys Res, 2003, 108: 2048

6 Montelli R, Nolet G, Dahlen F A, et al. Finite-frequency tomography reveals a variety of plumes in the mantle. Science, 2004, 303: 338343

7 Lei J S, Zhao D P, Steinberger B, et al. New seismic constraints on the upper mantle structure of the Hainan plume. Phys Earth Planet Inter, 2009, 173: 33-50

8 Yan Q S, Shi X F. Hainan mantle plume and the formation and evolution of the South China Sea (in Chinese). Geol J Chin Univ, 2007, 13: $311-322$

9 Chung S L, Cheng H, Jahn B-M, et al. Major and trace element, and $\mathrm{Sr}-\mathrm{Nd}$ isotope constraints on the origin of Paleogene volcanism in South China prior to the South China Sea opening. Lithos, 1997, 40: 203-220

10 Xu Y G, Sun M, Yan W, et al. Xenolith evidence for polybaric melting and stratification of the upper mantle beneath South China. J Asian Earth Sci, 2002, 20: 937-954

11 Yan P, Deng H, Liu H L, et al. The temporal and spatial distribution of volcanism in the South China Sea region. J Asian Earth Sci, 2006, 27: 647-659

12 Lee T Y, Lo C H, Chung S L, et al. ${ }^{40} \mathrm{Ar} /{ }^{39} \mathrm{Ar}$ dating result of Neogene basalts in Vietnam and its tectonic implication. In: Flower M, Chung S-L, Lo C-H, et al., eds. Mantle Dynamics and Plate Interactions in East Asia. Amer Geophys Union Monogr, 1998, 27: 317-330

13 Niu Y L, Hékinian R. Ridge suction drives plume-ridge interactions (Chapter 9). In: Hékinian R, Stoffers P, eds. Oceanic Hotspots. New York: Springer-Verlag, 2004. 285-307

14 Niu Y L, Batiza R. An empirical method for calculating melt compositions produced beneath mid-ocean ridges: Application for axis and off-axis (seamounts) melting. J Geophys Res, 1991, 96: 21753-21777

15 Ellam R M. Lithospheric thickness as a control on basalt geochemistry. Geology, 1992, 20: 153-156

16 Langmuir C H, Klein E M, Plank T. Petrological systematics of mid-ocean ridge basalts: Constraints on melt generation beneath ocean ridges. In: Morgan J P, Blackman D K, Sinton J M, eds. Mantle Flow and Melt Generation at Mid-ocean Ridges. Washington DC: AGU Geophys Monogr, Vol. 71, 1992, 71: 183-280

17 Haase K M. The relationship between the age of the lithosphere and the composition of oceanic magmas: Constraints on partial melting, mantle sources and the thermal structure of the plates. Earth Planet Sci Lett, 1996, 144: 75-92

18 Niu Y L, Hékinian R. Spreading rate dependence of the extent of mantle melting beneath ocean ridges. Nature, 1997, 385: 326-329

19 Xu Y G. Using basalt geochemistry to constrain Mesozoic-Cenozoic evolution of the lithosphere beneath North China Craton (in Chinese). Earth Sci Front, 2006, 13: 93-104

20 Humphreys E R, Niu Y L. On the composition of ocean island basalts (OIB): The effects of lithospheric thickness variation and mantle metasomatism. Lithos, 2009, 112: 118-136

21 Niu Y L, Wilson M, Humphreys E R, et al. The origin of intra-plate ocean island basalts (OIB): The lid effect and its geodynamic implications. J Petrol, 2011, 52: 1443-1468

22 Fram M S, Lesher C F. Geochemical constraints on mantle melting during creation of the North Atlantic basin. Nature, 1993, 363: 712715

23 McKenzie D, Bickle M J. The volume and composition of melt generated by extension of the lithosphere. J Petrol, 1988, 29: 625-679

24 Menzies M A. Archaean, Proterozoic, and Phanerozoic lithospheres. In: Menzies M A, ed. Continental Mantle. Oxford: Oxford Science Publications, 1990. 67-86

$25 \mathrm{Xu}$ Y G. Basaltic magmatism in continental extensional environment: Nature and dynamics. In: Zheng Y F, ed. Advances in Chemical Geodynamics (in Chinese). Beijing: Science Press, 1999. 119-167

26 DePaolo D J, Daley E E. Neodymium isotopes in basalts of the southwest basin and range and lithospheric thinning during continental extension. Chem Geol, 2000, 169: 157-185

27 Arndt N T, Christensen U. The role of lithospheric mantle in continental flood volcanism-thermal and geochemical constraints. J Geophys 
Res, 1992, 97: 10967-10981

28 Jaques A L, Green D H. Anhydrous melting of peridotite at 0-15 kb pressure and the genesis of tholeiitic basalts. Contrib Mineral Petrol, 1980, 73: 287-310

29 Kushiro I. Partial melting experiments on peridotite and origin of mid-ocean ridge basalt. Ann Rev Earth Planet Sci, 2001, 29: 71-107

30 Green D H, Ringwood A E. The "genesis" of basaltic magmas. Contrib Mineral Petrol, 1967, 15: 103-109

31 McKenzie D, O’Nions R K. Partial melt distribution from inversion of rare earth element concentrations. J Petrol, 1991, 32: 1021-1091

32 O'Neill H S C. The transition between spinel lherzolite and garnet lherzolite, and its use as a geobarometer. Contrib Mineral Petrol, 1981, 77: 185-194

33 Robinson J A, Wood B J. The depth of the spinel to garnet transition at the peridotite solidus. Earth Planet Sci Lett, 1998, 164: 277-284

34 Blundy J, Dalton J. Experimental comparison of trace element partitioning between clinopyroxene and melt in carbonate and silicate systems, and implications for mantle metasomatism. Contrib Mineral Petrol, 2000, 139: 356-371

35 Klein E M, Langmuir C H. Global correlations of ocean ridge basalt chemistry with axial depth and crustal thickness. J Geophys Res, 1987, 92: 8089-8115

36 Klein E M, Langmuir C H. Local versus global variations in ocean ridge basalt composition: A reply. J Geophys Res, 1989, 94: 42414252

37 Niu Y L, O'Hara M J. Global correlations of ocean ridge basalt chemistry with axial depth: A new perspective. J Petrol, 2008, 49: 633-664

38 Kinzler R. Melting of mantle peridotite at pressure approaching the spinel to garnet transition: Application to mid-ocean ridge basalt petrogenesis. J Geophys Res, 1997, 102: 853-874

39 Wang K, Plank T, Walker J D, et al. A mantle melting profile across the basin and range, SW USA. J Geophys Res, 2002, 107: 2017

40 Zhang H H, Xu Y G, Ge W C, et al. Geochemistry of late MesozoicCenozoic basalts in Yitong-Datun area, Jilin Province and its implication (in Chinese). Acta Petrol Sin, 2006, 22: 1579-1607

41 Campbell I H. Identication of ancient mantle plumes. In: Ernst R E, Buchan K, eds. Mantle Plumes: Their Identication Through Time. Geol Soc Am Spe Pap, 2001, 352: 5-22

$42 \mathrm{Xu} \mathrm{Y} \mathrm{G,} \mathrm{He} \mathrm{B,} \mathrm{Huang} \mathrm{X} \mathrm{L,} \mathrm{et} \mathrm{al.} \mathrm{Testing} \mathrm{plume} \mathrm{hypothesis} \mathrm{in} \mathrm{the}$ Emeishan large igneous province. Episodes, 2007, 30: 32-42

43 Hart S R, Hauri E H, Oschmann L A, et al. Mantle plume and entrainment: Isotopic evidence. Science, 1992, 256: 517-520

44 Zindler A, Hart S R. Chemical geodynamics. Ann Rev Earth Planet Sci, 1986, 14: 493-571

45 Niu Y L, Collerson K D, Batiza R, et al. The origin of E-type MORB at ridges far from mantle plumes: The East Pacific Rise at $11^{\circ} 20^{\prime} \mathrm{N}$. J Geophys Res, 1999, 104: 7067-7087

46 Zhang M, O'Reilly S Y, Chen D G. Location of Pacific and Indian mid-ocean ridge-type mantle in two time slices: Evidence from $\mathrm{Pb}, \mathrm{Sr}$, and $\mathrm{Nd}$ isotopes for Cenozoic Australian basalts. Geology, 1999, 27: 39-42

47 Xu Y G, Zhang H H, Qiu H N, et al. Oceanic crust components in continental basalts from Shuangliao, Northeast China: Derived from the mantle transition zone? Chem Geol, 2011, in revision

48 Zhu B Q, Wang H F, Mao C X, et al. Geochronology and Nd-Sr-Pb isotopic evidence for mantle source in the ancient subduction zone beneath Sanshui basin, China. Chin J Geochem, 1989, 8: 65-71

49 Zou H P, Li P L, Rao C T. Geochemistry of Cenozoic volcanic rocks in Zhujiangkou Basin and its geodynamic significance. Geochimia, 1995, 24: 33-45

50 Wang X J, Wu M, Liang D, et al. Some geochemical characteristics of basalts in the South China Sea (in Chinese). Geochimia, 1984, (4): 332-340

51 Kudrass H R, Wiedicke M, Cepek P, et al. Mesozoic and Cainozoic rocks dredged from the South China Sea (Reed Bank area) and Sulu Sea and their significance for plate-tectonic reconstructions. Mar Petrol Geol, 1986, 3: 19-30

52 Yan Q S, Shi X F, Wang K S, et al. Major, trace elements and
$\mathrm{Sr}-\mathrm{Nd}-\mathrm{Pb}$ isotope study of Cenozoic alkali basalts of the South China Sea (in Chinese). Sci China Ser D-Earth Sci, 2008, 51: 550-566

53 Han X Q. Ocean ridge basalt of Southwestern subbasin in the South China Sea: Rock geochemistry and geochronology constraints of South China Sea. "South China Sea evolution study of the major research plan" 2011 Annual Start Meeting (in Chinese). Shanghai, 2011, S1-O-12: 26-27

54 Zhu B Q, Wang H F. Nd-Sr-Pb isotopic and chemical evidence for the volcanism with MORB-OIB source characteristics in the Leiqiong area, China (in Chinese). Geochimica, 1989, 18: 193-201

55 Chen J. Quaternary Geology of Guangdong Tianyang Volcano Lake (in Chinese). Beijing: Geological Publishing House, 1990

56 Sun J. Cenozoic volcanic activity in the Northern South China Sea and Guangdong coastal area (in Chinese). Mar Geol Quat Geol, 1991, 11: 45-65

57 Huang Z, Cai F, Han Z, et al. Quaternary Volcanoes of Leiqiong (in Chinese). Beijing: Science Press, 1993

58 Jia D, Qiu X, Hu R, et al. Geochemical nature of mantle reservoirs and tectonic setting of basalts in Beibu Gulf and its adjacent region (in Chinese). Tropic Oceanol, 2003, 22: 30-39

59 Barr S M, Macdonald A S. Geochemistry and geochronology of late Cenozoic basalts of Southeast Asia: Summary. Geol Soc Amer Bull, 1981, 92: 508-512

60 Zhu B-Q, Wang H-F, Chen Y-W, et al. Geochronological and geochemical constraint on the Cenozoic extension of Cathaysian lithosphere and tectonic evolution of the border sea basins in East Asia. J Asian Earth Sci, 2004, 24: 163-175

61 Xu X S, O'Reilly S Y, Zhou X M, et al. A xenolith-derived geotherm and the crust-mantle boundary at Qilin, southeastern China. Lithos, 1996, 38: 41-62

$62 \mathrm{Xu} \mathrm{Y} \mathrm{G,} \mathrm{Lin} \mathrm{C} \mathrm{Y,} \mathrm{Shi} \mathrm{L} \mathrm{B.} \mathrm{The} \mathrm{geotherm} \mathrm{of} \mathrm{the} \mathrm{lithosphere} \mathrm{beneath}$ Qilin, SE China: A re-appraisal and implications for P-T estimation of Fe-rich pyroxenites. Lithos, 1999, 47: 181-193

63 Flower M F J, Zhang M, Chen C Y, et al. Magmatism in the South China Basin. 2. Post-spreading Quaternary basalts from Hainan Island, South China. Chem Geol, 1992, 97: 65-87

64 Tu K, Flower M F J, Carlson R W, et al. Magmatism in the South China Basin.1. Isotopic and trace-element evidence for an endogenous dupal mantle component. Chem Geol, 1992, 97: 47-63

65 Sun S-S, McDonough W F. Chemical and isotopic systematics of oceanic basalts: implications for mantle composition and processes. In: Saunders A D, Norry M J, eds. Magmatism in the ocean basins. Geol Soc Lond Spec Publ, 1989, 42: 313-345

66 Zhang M, Tu K, Xie G H, et al. Trace element and isotope geochemistry of Cenozoic basalts from Hainan island. In: Liu R X, ed. Geochronology and Geochemistry of Cenozoic Volcanic Rocks in China (in Chinese). Beijing: Seismological Press, 1992. 246-268

67 Zou H B, Zindler A, Xu X S, et al. Major, trace element, and Nd, Sr and $\mathrm{Pb}$ isotope studies of Cenozoic basalts in SE China: Mantle sources, regional variations, and tectonic significance. Chem Geol, 2000, 171: 33-47

68 Chung S L, Sun S S, Tu K, et al. Late Cenozoic basaltic volcanism around the Taiwan Strait, SE China: Product of lithosphere-asthenosphere interaction during continental extension. Chem Geol, 1994, 112: 1-20

69 Chung S L, Jahn B M, Chen S J, et al. Miocene basalts in northwestern Taiwan: Evidence for EM-type mantle sources in the continental lithosphere. Geochim Cosmochim Acta, 1995, 59: 549-555

70 Hoang N, Flower M. Petrogenesis of Cenozoic basalts from Vietnam: Implication for origins of a 'diffuse igneous province'. J Petrol, 1998, 39: 369-395

71 Zhou P B, Mukasa S B. Nd-Sr-Pb isotopic, and major and trace-element geochemistry of Cenozoic lavas from the Khorat Plateau, Thailand: Source and petrogenesis. Chem Geol, 1997, 137: 175-193

72 Hart S R. A large-scale isotope anomaly in the Southern Hemisphere mantle. Nature, 1984, 309: 753-757

73 Chen C-H, Lee C-Y, Shinjo R. Was there Jurassic paleo-Pacific subduction in South China: Constraints from ${ }^{40} \mathrm{Ar} /{ }^{39} \mathrm{Ar}$ dating, elemental and $\mathrm{Sr}-\mathrm{Nd}-\mathrm{Pb}$ isotopic geochemistry of the Mesozoic basalts. Lithos, 
2008, 106: 83-92

74 Wang Y J, Fan W M, Cawood P A, et al. Sr-Nd-Pb isotopic constraints on multiple mantle domains for Mesozoic mafic rocks beneath the South China Block hinterland. Lithos, 2008, 106: 397-308

75 Tapponnier P, Peltzer G, Armijo R, et al. Propagating extrusion tectonics in Asia: New insights from simple experiments with plasticine. Geology, 1982, 10: 611-616

76 Chung S L, Lee T Y, Lo C H, et al. Intraplate extension prior to continental extrusion along the Ailao Shan Red River shear zone. Geology, 1997, 25: 311-314

77 Clift P, Lin J, Barkhausen U. Evidence of low flexural rigidity and low viscosity lower continental crust during continental break-up in the South China Sea. Mar Petrol Geol, 2002, 19: 951-970

78 Zhao D. Seismic images under 60 hotspots: Search for mantle plumes. Gondwana Res, 2007, 12: 335-355

79 Wang X C, Li Z X, Li X H, et al. Temperature, pressure, and composition of the mantle source region for late Cenozoic basalts in Hainan Island, Southeastern Asia: Results of a young thermal mantle plume close to subduction zones? J Petrol, 2011, doi:10.1093/petrology/egr061

80 Ho K S, Chen J-C, Juang W-S. Geochronology and geochemistry of late Cenozoic basalts from the Leiqiong area, southern China. J Asian Earth Sci, 2000, 18: 307-324

81 Zou H B, Fan Q C. U-Th isotopes in Hainan basalts: Implications for sub-asthenospheric origin of EM2 mantle endmember and the dynamics of melting beneath Hainan Island. Lithos, 2010, 116: 145-152

82 Lin J L, Fuller M, Zhang W Y. Preliminary Phanerozoic polar wander paths for the North and South China blocks. Nature, 1985, 313: 444-449

83 Ridd M F. South-East Asia as a part of Gondwanaland. Nature, 1971, 234: 531-533

84 Xu X S, O’Reilly S Y, Griffin W L, et al. Enrichment of upper mantle peridotite: Petrological, trace element and isotopic evidence in xenoliths from SE China. Chem Geol, 2003, 198: 163-188

85 Wu H H, Tsai Y B, Lee T Y, et al. 3-D shear wave velocity structure of the crust and upper mantle in South China Sea and its surrounding regions by surface wave dispersion analysis. Mar Geophys Res, 2004, 25: 5-27

86 Hofmann A W. Chemical differentiation of the Earth: The relationship between mantle, continental crust, and the oceanic crust. Earth Planet Sci Lett, 1988, 90: 297-314

87 White W M, Dupre B. Sediment subduction and magma genesis in the Lesser Antilles: Isotopic and trace element constraints. J Geophys Res, 1986, 91: 5927-5941

88 Mukasa S B, McCabe R, Gill J B. Pb isotopic compositions of volcanic rocks in the west and east Philippines arcs: Presence of the Dupal isotopic anomaly. Earth Planet Sci Lett, 1987, 84: 153-164

89 Zhang M, Tu K, Xie G H, et al. Subduction-modified subcontinental mantle in south China: Trace element and isotope evidence in basalts from Hainan Island. Chin J Geochem, 1996, 15: 1-19

90 Sims K W W, DePaolo D J, Murrell M T, et al. Porosity of the melting zone and variations in the solid mantle upwelling rate beneath Hawaii: inferences from ${ }^{238} \mathrm{U}_{-}{ }^{230} \mathrm{Th}_{-}{ }^{226} \mathrm{Ra}$ and ${ }^{235} \mathrm{U}_{-}{ }^{231} \mathrm{~Pa}$ disequilibria. Geochim Cosmochim Acta, 1999, 63: 4119-4138

91 White W M, McKenzie D. Magmatism at rift zone: The generation of volcanic continental margins and flood basalts. J Geophys Res, 1989, 94: 7685-7729

92 Menzies M A, Klemperer S L, Ebinger C J, et al. Characteristics of volcanic rifted margins. In: Menzies M A, Klemperer S L, Ebinger C J, et al., eds. Volcanic Rifted Margins. Boulder, Colorador, Geological Society of America Special Paper, 2002, 363: 1-14

93 Parsons B, Sclater J G. Analysis of variation of ocean-floor bathymetry and heat-flow with age. J Geophys Res, 1977, 82: 803-827

94 Morgan J P, Smith W H F. Flattening of the sea-floor depth age curve as a response to asthenospheric flow. Nature, 1992, 359: 524-527

95 Stein C A, Stein S. A model for the global variation in oceanic depth and heat-flow with lithospheric age. Nature, 1992, 359: 123-129

96 Kawakatsu H, Kumar P, Takei Y, et al. Seismic evidence for sharp lithosphere-asthenosphere boundaries of oceanic plates. Science, 2009, 324: 499-502

97 Kumar P, Kawakatsu H. Imaging the seismic lithosphere-asthenosphere boundary of the oceanic plate. Geochem Geophys Geosyst, 2011, 12: Artn Q01006

98 Hauri E. SIMS analysis of volatiles in silicate glasses. 2. Isotopes and abundances in Hawaiian melt inclusions. Chem Geol, 2002, 183: 115-141

99 Sobolev A V, Danyushevsky L V. Petrology and geochemistry of boninites from the north termination of the Tonga trench-Constraints on the generation conditions of primary high-Ca boninite magmas. $\mathrm{J}$ Petrol, 1994, 35: 1183-1211

100 Sobolev A V, Hofmann A W, Nikogosian I K. Recycled oceanic crust observed in 'ghost plagioclase' within the source of Mauna Loa lavas. Nature, 2000, 404: 986-990

Open Access This article is distributed under the terms of the Creative Commons Attribution License which permits any use, distribution, and reproduction in any medium, provided the original author(s) and source are credited. 